\title{
New and little known taxa of the endemic Afrotropical subfamily Mimolibnetinae (Coleoptera: Lycidae)
}

\section{Новые и малоизвестные таксоны эндемичного афротропического подсемейства Mimolibnetinae (Coleoptera: Lycidae)}

\author{
Sergey V. Kazantsev \\ С.В. Казанцев
}

Insect Centre, Donetskaya 13-326, Moscow 109651, Russia.

Инсект-центр, ул. Донецкая 13-326, Москва 109651, Россия; e-mail: kazantss@mail.ru

KEY WORDS: Coleoptera, Lycidae, Mimolibnetinae, new tribe, new genus, new subgenus, new species, systematics, taxonomy, Afrotropical region.

КЛЮЧЕВЫЕ СЛОВА: Coleoptera, Lycidae, Mimolibnetinae, новая триба, новый вид, систематика, таксономия, афротропический регион.

ABSTRACT. Lampyrolycus Burgeon, 1937 is transferred from Dexorini to Mimolibnetinae, and a new tribe, Lampyrolycini tr.n., a new genus, Eulycus gen.n., and a new subgenus, Eulycus subgen. Lobentis subgen.n., are described in this neotenic subfamily of net-winged beetles. Mimolibnetis patruelis Kazantsev, 2013 is transferred to Eulycus s.str. as E. (s.str.) patruelis (Kazantsev, 2013), comb.n. and Mimolibnetis obscurus Pic, 1936 is transferred to Eulycus subgen. Lobentis subgen.n. as E. (L.) obscurus (Pic, 1936), comb.n. A new species, E. (L.) telnovi sp.n., is described from Gabon. Provided is a key to all nine known species of Mimolibnetinae, with a map of their distribution and photos of six of them.

РЕЗЮМЕ. Lampyrolycus Burgeon, 1937 переносится из Dexorini в Mimolibnetinae, описывается новая триба, Lampyrolycini tr.n., новый род, Eulycus gen.n., и новый подрод, Eulycus subgen. Lobentis subgen.n., в этом неотеничном подсемействе жуковкраснокрылов. Mimolibnetis patruelis Kazantsev, 2013 переносится в Eulycus s.str. как E. (s.str.) patruelis (Kazantsev, 2013), comb.n., a Mimolibnetis obscurus Pic, 1936 переносится в Eulycus subgen. Lobentis subgen.n. как E. (L.) obscurus (Pic, 1936), comb.n. Описывается новый вид, E. (L.) telnovi sp.n., из Габона. Предлагается определительная таблица для всех девяти известных видов Mimolibnetinae, с картой их распространения и иллюстрациями шести из них.

\section{Introduction}

The subfamily Mimolibnetinae was erected to accommodate the genus Mimolibnetis Pic, 1936 [Kazan- tsev, 2013]. Mimolibnetis, the first apparently neotenic African lycid taxon with 10-segmented antennae and reduced mandibles, was introduced in a paper on "different novelties" [Pic, 1936], with two species attributed to the genus, each known from just one type specimen. Only after over sixty years were four more $\mathrm{Mi}$ molibnetis specimens discovered belonging in three new species [Kazantsev, 1999]. Recently, the genus was redescribed, with one more new species added, and separated on the basis of a phylogenetic analysis as a subfamily [Kazantsev, 2013, 2015].

The monospecific genus Lampyrolycus Burgeon, 1937 was the only other neotenic African genus with 10segmented antennae and reduced mandibles [Burgeon, 1937]. It was redescribed along with Mimolibnetis, and a second species was attributed to it [Kazantsev, 1999]. Nevertheless, its systematic position has so far been unclear and it was not placed in either of the two Afrotropical neotenic lineages, Mimolibnetini and Dexorini in the latest revisional paper [Kazantsev, 2013], although being occasionally referred to Dexorini [e.g., Kazantsev, 2005; Bocáková, 2014].

The study of new lycids collected in Gabon by Dr. Telnov in 2016, as well as the re-examination of the old material, has led to the discovery of several new taxa of Mimolibnetinae, including another new species, and necessitates certain taxonomic changes. These taxa are described and these changes are proposed below, with habitus and aedeagus photographs provided for most of the previously described species.

The following acronyms are used in this paper: ICM - Insect Center, Moscow; MNHN — Muséum national d'Histoire naturelle, Paris; MNCN — Museo

How to cite this article: Kazantsev S.V. 2018. New and little known taxa of the endemic Afrotropical subfamily Mimolibnetinae (Coleoptera: Lycidae) // Russian Entomol. J. Vol.27. No.2. P.143-151. doi: 10.15298/ rusentj.27.2.04 
Nacional de Ciencias Naturales, Madrid; MRAC Musée royal de l'Afriqie centrale, Tervuren; NME Naturkundemuseum, Erfurt.

\section{Material and Methods}

For examination the beetles were relaxed in water, then their detached abdomina were kept for several hours in $10 \% \mathrm{KOH}$ at room temperature. The $\mathrm{KOH}$ treated aedeagi were then placed on slides with glycerin or Faure's Berlese media for photographing.

MSP-1 zoom stereoscopic dissecting microscope with $\mathrm{x} 8-\mathrm{x} 80$ and Micromed-2/3-20 zoom stereoscopic light microscope with $\mathrm{x} 100-\mathrm{x} 400$ magnification range were used. Photographs were taken with Canon EOS 6D camera and Canon MP-E $65 \mathrm{~mm}$ lens.

\section{Taxonomy}

\section{Mimolibnetinae Kazantsev, 2013}

Type genus: Mimolibnetis Pic, 1936 (original designation).

REMARKS. The taxon Mimolibnetinae was characterized by the 10-segmented antennae, elongate head with long gula, fused to gula prementum, reduced mandibles, semifused with mesepisternum mesoventrite, scutellum separated from anterior margin of scutum by median suture, developed elytral reticulation, obliquely connected trochanters, contiguous hind coxae, present tibial spurs, abdominal spiracles at the edge of tergites and evident lateral apodemes of the phallobase, with the tergal location of abdominal spiracles, fused to gula prementum, semi-fused condition of mesoventrite, and obliquely connected to femurs trochanters hypothesised to be autapomorphous for the lineage [Kazantsev, 2013]. Mimolibnetinae are very different from the other neotenic Afrotropical lineage, Dexorini (belonging in the subfamily Leptolycinae) [Kazantsev, 2013], where the antennae are 11-segmented, head is transverse with short gula, labium is free, mandibles are well developed, mesoventrite is separated from mesepisternum by a complete suture, scutellum reaches anterior margin of scutum, elytral reticulation and tibial spurs are absent, hind coxae are distinctly separated, abdominal spiracles are located at the edge of sternites and there are no lateral apodemes of the phallobase, the two taxa sharing only the obliquely connected trochanters, which were hypothesised to be in homoplastic condition.

The genus Lampyrolycus has been referred to neither of the above mentioned Afrotropical neotenic groups, as many of its crucial characters remained unexamined [e.g., Kazantsev, 2013]. Its re-examination (the type specimen of $L . b i$ color Kazantsev, 1999 was studied) shows that it shares many of the above-mentioned characters of Mimolibnetinae, i.e., the 10-segmented antennae, elongate head with long gula, reduced mandibles, scutellum connected to anterior scutal margin by median suture, developed elytral reticulation, obliquely connected trochanters, noticeable tibial spurs and lateral apodemes of the phallobase. However, the labium in Lampyrolycus is not fused to gula, the mesoventrite is separated from mesepisternum by a complete suture, the hind coxae are distinctly separated and abdominal spiracles are located at the edge of sternites, as in most of lycids. Nevertheless, Lampyrolycus seems to agree with Mimolibnetinae con- siderably more than with any other neotenic group, including Dexorini, because the combination of its 10-segmented antennae, elongate head with long gula, reduced mandibles, scutellum connected to anterior scutal margin by median suture, developed elytral reticulation, tibial spurs and lateral apodemes of the phallobase, is shared only by Mimolibnetinae. It is therefore transferred from Dexorini to Mimolibnetinae and placed in a new tribe, Lampyrolycini tr.n. Hence, the autapomorphies of the subfamily appear to be limited to the combination of 10-segmented antennae, elongate head with long gula, reduced mandibles, scutellum connected to anterior scutal margin by median suture, noticeable tibial spurs and lateral apodemes of the phallobase, while the developed elytral reticulation is hypothesised to be its plesiomorphy and the obliquely connected trochanters its homoplasy with Dexorini.

COMPOSITION. Mimolibnetinae includes two tribes, Mimolibnetini Kazantsev, 2013 and Lampyrolycini Kazantsev, tr.n.

The monotypic genus Fernandum Pic, 1924, with pectinate 10-segmented antennae [Pic, 1924], may also belong in Mimolibnetinae. Its only specimen, however, has not been found in the Muséum national d'Histoire naturelle in Paris, where the Pic collection is deposited. The also monotypic genus Lolodorfus Bocáková, 2014 may prove to belong in Mimolibnetinae as well, although it has 11-segmented antennae. However, this genus needs to be re-examined, as the description lacks some of the characters necessary for its proper systematic placement: it is not even clear if the type specimen has abdomen, as no mention is made of the abdominal or aedeagal structures [Bocáková, 2014].

Mimolibnetini Kazantsev, 2013

Type genus: Mimolibnetis Pic, 1936 (original designation).

COMPOSITION. Mimolibnetini includes two genera, Mimolibnetis Pic, 1936 and Eulycus, gen.n.

\section{Mimolibnetis Pic, 1936}

Type species: Mimolibnetis apicalis Pic, 1936 (subsequsent designation by Kazantsev, 1999).

COMPOSITION. Mimolibnetis includes four species, $M$. apicalis Pic, 1936, M. baguenai Kazantsev, 1999, M. indigenus Kazantsev, 1999 and M. ruwenzoriensis Kazantsev, 1999.

DISTRIBUTION. Western part of the Afrotropical region (Equatorial Guinea and Congo) (Fig. 1).

BIOLOGY. Our knowledge of the Mimolibnetis biology is limited, also because all its species are known from just one or two specimens. In one case (M. ruwenzoriensis) the species was collected in alpine associations with Ericetum at $3310 \mathrm{~m}$ in the Ruwenzori Massif, in another (M. indigenus) in humus in a swamp forest ('humus en forêt marécageuse').

\section{Mimolibnetis apicalis Pic, 1936}

Figs 2, 10-11.

Mimolibnetis apicalis Pic, 1936: 33.

MATERIAL. Lectotype, $\sigma^{7}$, 'Congo, Kani', 'Mimolibnetis apicalis n. sp.' (Pic's manuscript labels) (MNHN).

DISTRIBUTION. Known only from Congo (Fig. 1).

Mimolibnetis baguenai Kazantsev, 1999

Mimolibnetis baguenai Kazantsev, 1999: 16.

MATERIAL. Holotype, o', 'Alto Benito (Miko'meseng), Guinea Espanola, Dr. L. Baguena', 'Holotype', 'Mimolibnetis baguenai sp.n., S. Kazantsev det, 1999' (printed labels) (MNSN).

DISTRIBUTION. Known only from Equatorial Guinea (Fig. 1). 
Mimolibnetis indigenus Kazantsev, 1999

Mimolibnetis indigenus Kazantsev, 1999: 16.

MATERIAL. Holotype, O', 'Mus. Roy. Afr. centr., Tschuapa: Terr. Ikela, ruiss. Befali, IX.1959, B.99 N. Leleup', 'Biot. O'99: Humus en forêt marécageuse', 'Holotype', 'Mimolibnetis indigenus sp.n., S. Kazantsev det, 1999' (printed labels) (MRAC).

DISTRIBUTION. Known only from Congo (Fig. 1).
Mimolibnetis ruwenzoriensis Kazantsev, 1999

Figs 3-4, 12-13.

Mimolibnetis ruwenzoriensis Kazantsev, 1999: 14.

MATERIAL. Paratype, $\sigma^{7}$, 'Congo: P.N.A., Massif Ruwenzori, Mahungu, camp des porteurs, 3310 m, Ericetum, 15.VII.1963, RP. M.-J. Celis leg.', 'Paratype', 'Mimolibnetis ruwenzoriensis sp.n., S. Kazantsev des. 1999' (printed labels) (ICM).

DISTRIBUTION. Known only from the Ruwenzori Massif in eastern Congo (Fig. 1).

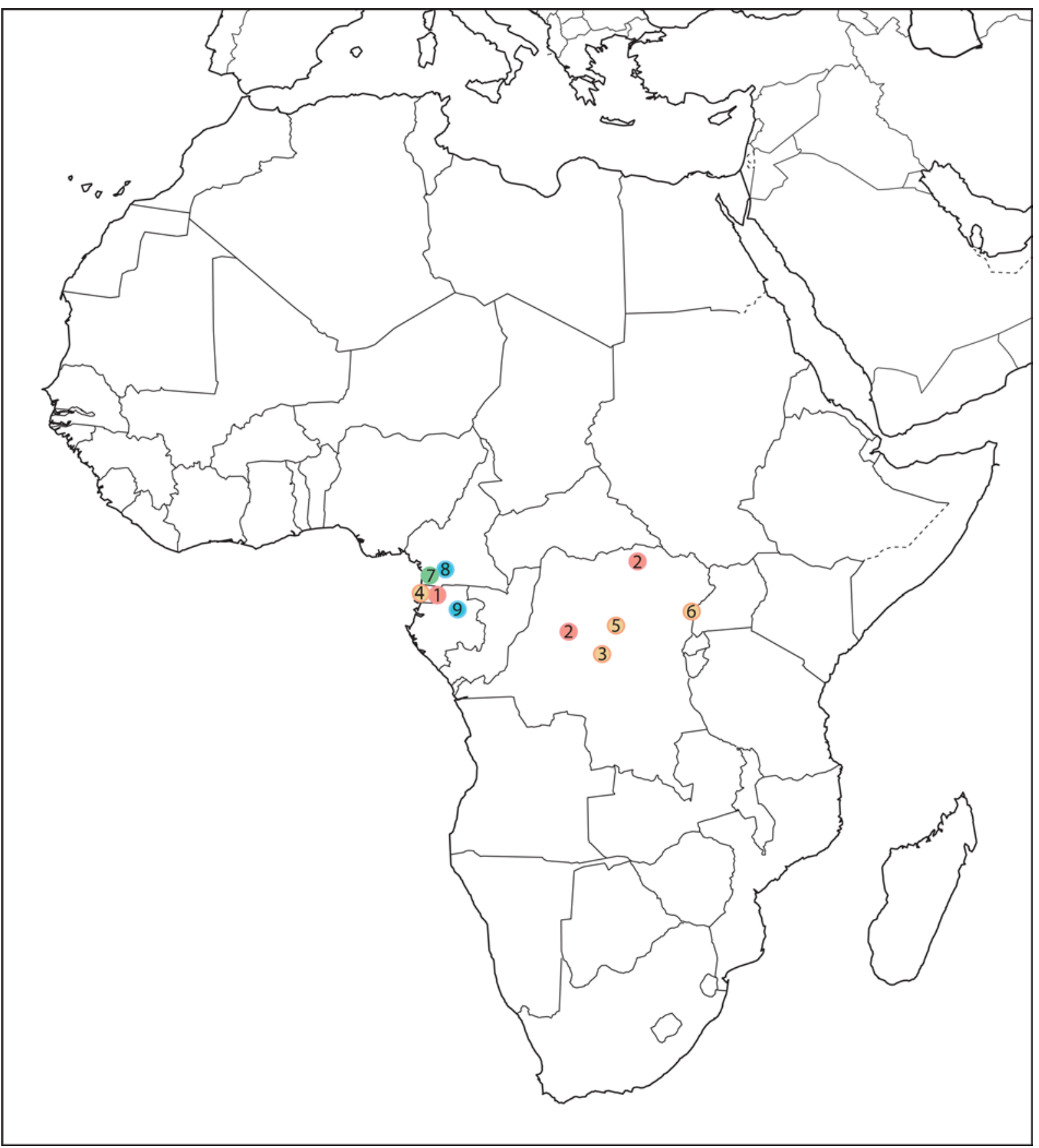

Fig. 1. Distribution of Mimolibnetinae species: 1 - Lampyrolycus bicolor; 2 - L. hulstaerti; 3 -Mimolibnetis apicalis; 4 - M. baguenai; 5-M. indigenus; $6-$ M. ruwenzoriensis; 7 - Eulycus (s.str.) patruelis; $8-$ Eulycus (Lobentis) obscurus; $9-E$ (L.) telnovi sp.n.

Рис. 1. Распространение видов Mimolibnetinae: 1 - Lampyrolycus bicolor; 2 - L. hulstaerti; 3 - Mimolibnetis apicalis; $4-M$. baguenai; 5-M. indigenus; 6 - M. ruwenzoriensis; 7 - Eulycus (s.str.) patruelis; 8 - Eulycus (Lobentis) obscurus; 9 - E (L.) telnovi sp.n. 


\section{Eulycus Kazantsev, gen.n.}

Type species: Mimolibnetis patruelis Kazantsev, 2013: 11

DESCRIPTION. Male. Alate, slender, elongate (Fig. 5). Head elongate, parallel-sided behind eyes. Fastigium acute, ca. 50 degrees. Eyes moderately large, spherical. Labrum minute, transverse, lying mostly inside epistoma. Mandibles vestigial. Maxillary palps slender, 4-segmented, with ultimate palpomere narrow and pointed distally. Labium greatly reduced, prementum fused to gula, palps one-segmented (Fig. 6). Gula long. Antennal prominence conspicuous, semioval; antennal sockets separated by minute lamina. Antenna 10 -segmented, moderately long, not attaining to elytral apices, filiform; antennomere 2 transverse, much shorter than antennomere 3 and consequent antennomeres; hairy pubescence moderately long, scarce and erect, scaliform pubescence absent (Fig. 5).

Pronotum conspicuously transverse, semi-trapezoidal, finely alveolate, with inconspicuous narrow complete median carina and transverse heart-shaped structure formed by paired folds in posterior half; anterior margin slightly convex, posterior margin conspicuously bisinuate; anterior angles rounded, posterior angles small and acute (Fig. 5). Prosternum short, T-shaped, slightly emarginate medially at anterior margin, with short posterior process. Thoracic spiracles small, elongate. Mesoventrite fused to mesepisternum, transverse, straight anteriorly, without median suture. Mesonotum with scutellum not attaining to anterior margin, mesoscutal halves not divided; scutellum with elongate and slightly emarginate distally postnotal plate (Fig. 7). Elytra long, over 7 times longer than pronotum, slightly dehiscent and slightly narrowing posteriorly, with four primary costae, costa 1 attaining elytral third and costae 3 and 4 strongest near humerus (Fig. 5); interstices with irregular double rows of cells; moderately long sub-erect pubescence uniform. Metanotum transverse, with straight and widened anteriorly scuto-scutellar ridge; allocristae about as long as scuto-scutellar ridge; intrascutal suture short, inconspicuous, emerging at distal third of scutum; prescutum with narrow median suture; scutellum without median suture; postnotal plate narrow, without median suture. Metaventrite elongate, with blunt posterior angles; discrimen (metasternal suture) attaining to about half of mesosternum. Metendosternite about 2 times shorter than metaventrite, narrow, parallel-sided, with inconspicuous lateral arms and narrow transverse suture.

Protrochantins very narrow, subequal in size to mesotrochantins. Pro-, meso- and metacoxae elongate, distally contiguous. Legs relatively robust; trochanters elongate, but considerably shorter than half of tibia, connected to femora obliquely; femurs robust, slightly flattened, tibiae straight, flattened and broad, serrate at outer margin, tibial spurs present; tarsomeres 1-4 narrow, without plantar pads, tarsomeres $1-5$ short, subequal in length, tarsomere 5 subequal in length to tarsomeres $1-5$ combined; all claws simple, narrow.

Tergites 6-7 only slightly produced at distal margin and pointed medially (Fig. 5). Abdominal spiracles located laterally on tergites near their edge. Paraproct elliptical; spiculum gastrale about as long as distal portion of sternite 9. Aedeagus symmetric, with elongate median lobe, developed roundish parameres and tapering proximally phallobase; parameres about 2 times shorter than median lobe (Figs 14-15).

Female. Presumably paedomorphic and larviform.

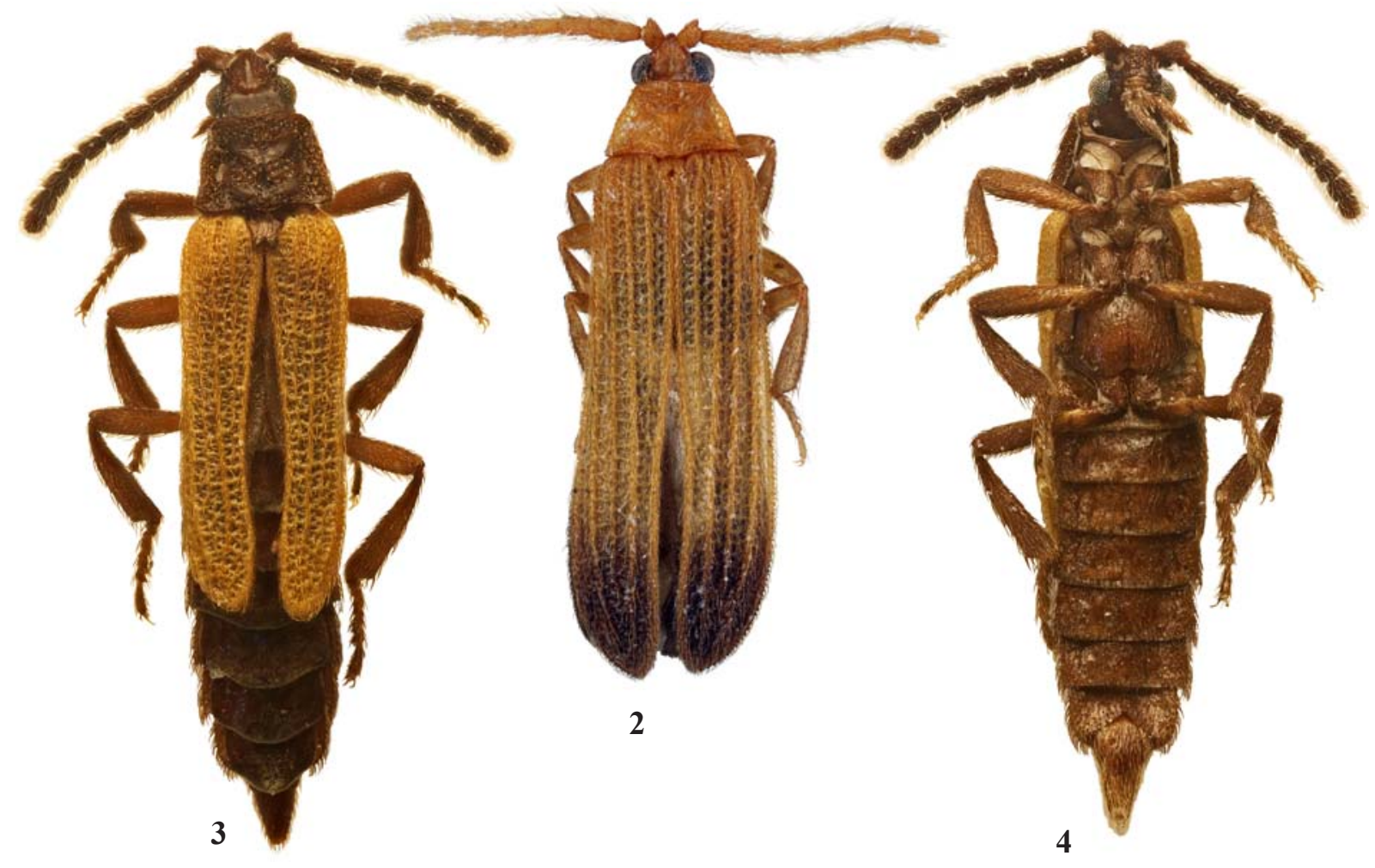

Figs 2-4. General view of Mimolibnetis spp., males: $2-$ M. apicalis, lectotype; $3-4-$ M. ruwenzoriensis, paratype; $2-3-$ dorsally; 4 - ventrally.

Рис. 2-4. Общий вид Mimolibnetis spp., самцы: 2 - M. apicalis, лектотип; 3-4 - M. ruwenzoriensis, паратип; 2-3 - сверху; $4-$ снизу. 
ETYMOLOGY. The name of the genus is derived from the genus name "Euanoma", alluding to certain similarity of its aedeagal structure to that of the aforesaid genus, and the genus name "Lycus". Gender masculine.

DIAGNOSIS. Eulycus gen.n. differs from Mimolibnetis by only slightly produced at distal margin and pointed medially tergites 6-7 (Fig. 5), as well as by the aedeagal structures, with median lobe about twice as long as parameres and tapering posteriorly phallobase (Figs 14-15).

COMPOSITION. Eulycus gen.n. is composed of two subgenera, Eulycus sensu stricto and Eulycus subgen. Lobentis, subgen.n.

DISTRIBUTION. Discovered in Cameroon and Gabon (Fig. 1).

BIOLOGY. The biological data on Eulycus gen.n. is not abundant. The two E. (s.str.) patruelis specimens were collected in a flight intercept trap at $35 \mathrm{~m}$ above sea level, while the only type specimen of $E$. (L.) telnovi sp.n. - in a UV light trap in secondary lowland rainforest at $480-540 \mathrm{~m}$.

\section{Eulycus (s.str.) Kazantsev, subgen.n.}

Type species: Mimolibnetis patruelis Kazantsev, 2013: 11 COMPOSITION. Eulycus (s.str.) includes only its type pecies.
DISTRIBUTION. South-western Cameroon (Fig. 1).

Eulycus (s.str.) patruelis (Kazantsev, 2013)

Figs 5-7, 14-15.

Mimolibnetis patruelis Kazantsev, 2013: 11.

MATERIAL: Holotype, $\sigma^{7}$, 'Cameroon, Southwest Prov., W Limbe, Bakingili, 35 m, FIT, 1-15.VII.2004, M. Fischer leg.', 'Holotype', 'Mimolibnetis patruelis sp.n., S. Kazantsev des. 2013' (ICM); paratype, $0^{7}$, Cameroon, Southwest Prov., W Limbe, Bakingili, 35 m, FIT, 1-15.VII.2004, M. Fischer leg.', 'Paratype', 'Mimolibnetis patruelis sp.n., S. Kazantsev des. 2013' (ICM).

DISTRIBUTION. Known only from Cameroon (Fig. 1).

Eulycus subgen. Lobentis Kazantsev, subgen.n.

Type species: Eulycus (Lobentis) telnovi Kazantsev, sp.n.

ETYMOLOGY. The name of the subgenus is derived from "lobus", the Latin for «lobe», alluding to the peculiar shape of median lobe of the aedeagus in its species, and the genus name "Mimolibnetis". Gender masculine.

DIAGNOSIS. Lobentis subgen.n. differs from the nominative subgenus by the elongate phallobase with short lateral apodemes and conspicuously curved or bent median lobe of the aedeagus (Figs 17-19).

COMPOSITION. Eulycus subgen. Lobentis, subgen.n.

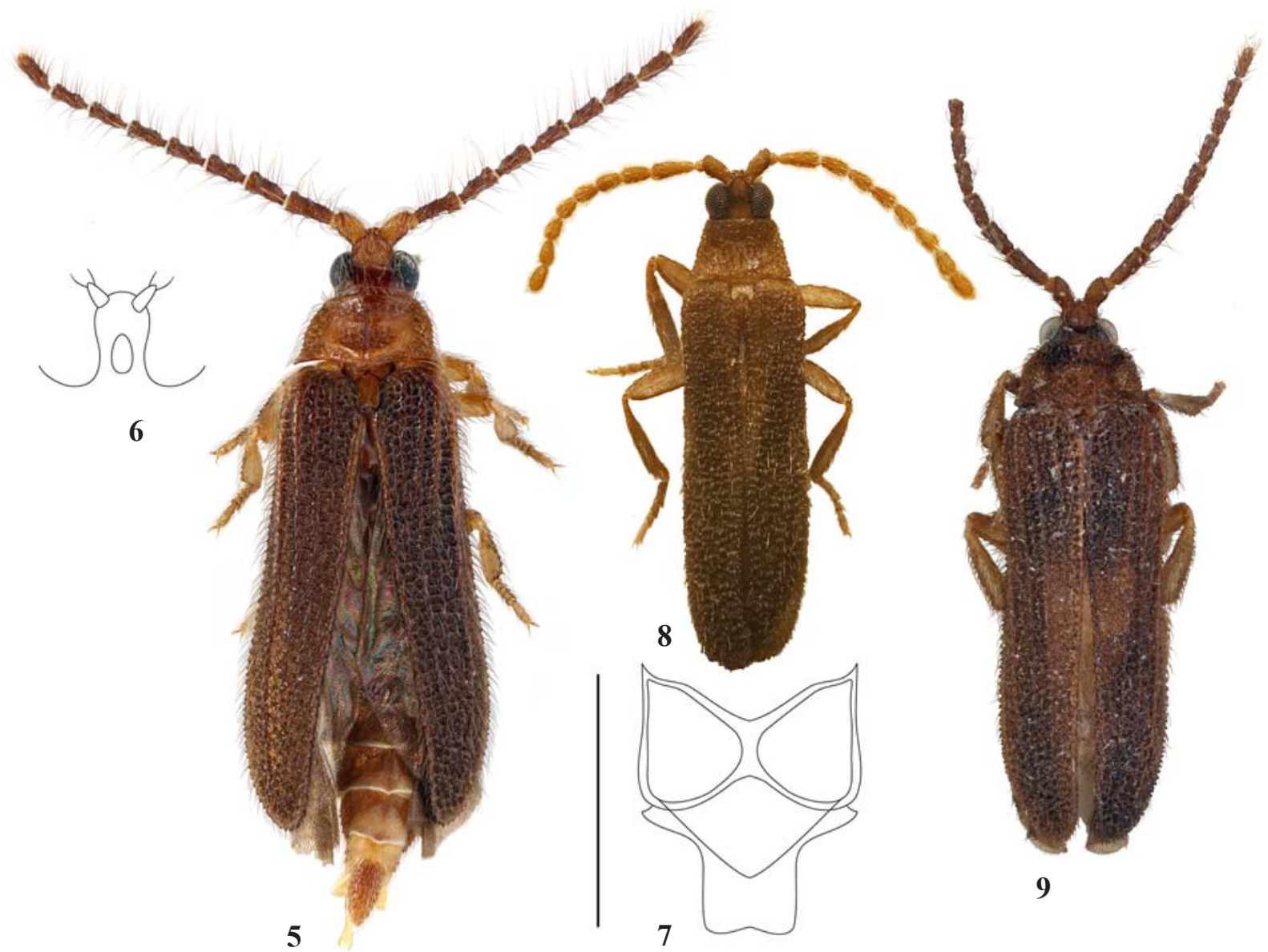

Figs 5-9. General view and details of Eulycus gen.n. spp., males: 5-7 - E. (s.str.) patruelis; $8-$ E. (Lobentis) telnovi sp.n.; $9-$ E. (L.) obscurus; 5-8 - holotypes; 9 - lectotype; 5, 8, 9- general view; 6 - labium; 7 - mesonotum; 5, 7-9 - dorsally; 6- ventrally. Scale bar: $0.5 \mathrm{~mm}$.

Рис. 5-9. Общий вид и детали строения Eulycus gen.n. spp., самцы: 5-7 - E. (s.str.) patruelis; $8-E$. (Lobentis) telnovi sp.n.; $9-E$. (L.) obscurus; 5-8 - голотипы; 9 - лектотип; 5, 8, 9 - общий вид; 6 - нижняя губа; 7 - мезонотум; 5, 7-9 - сверху; 6 - снизу. Масштабная линейка: 0,5 мм. 
includes two species, E. (L.) telnovi sp.n. and $E$. (L.) obscurus (Pic, 1936), comb.n.

DISTRIBUTION. Known only from Cameroon and Gabon (Fig. 1).

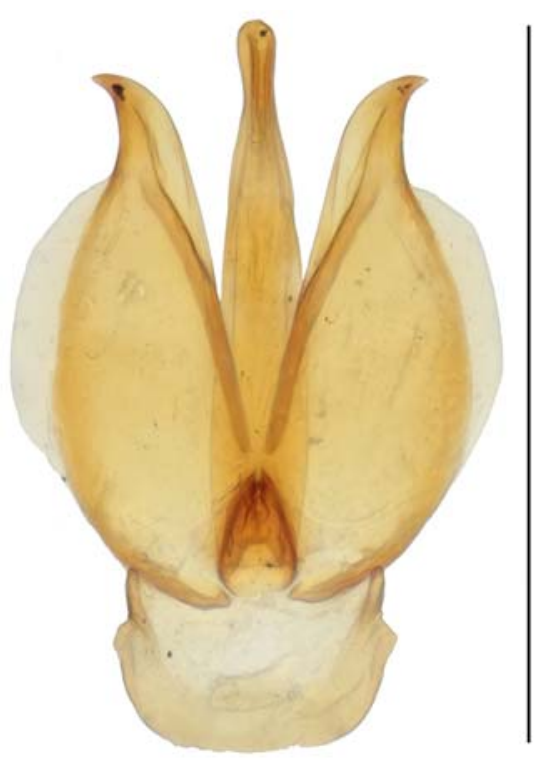

10

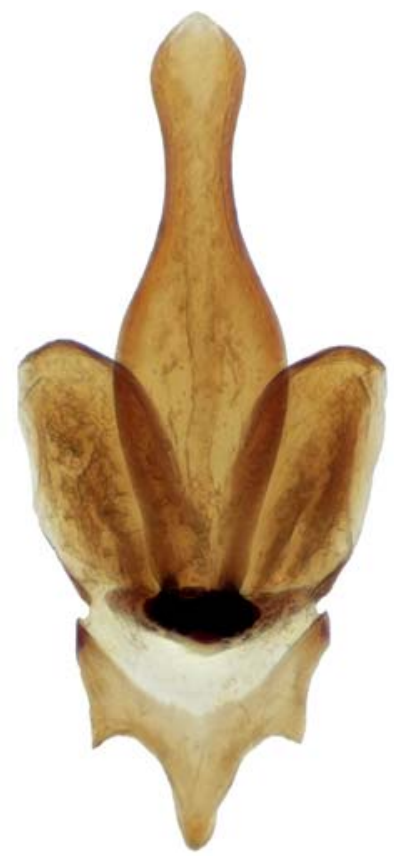

14

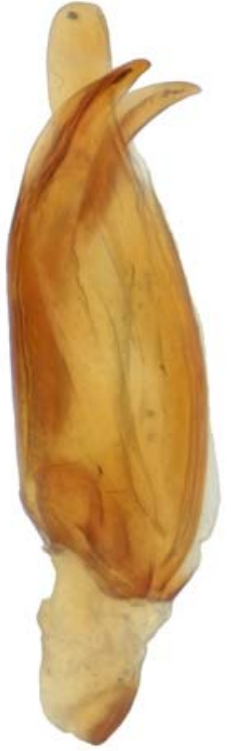

11

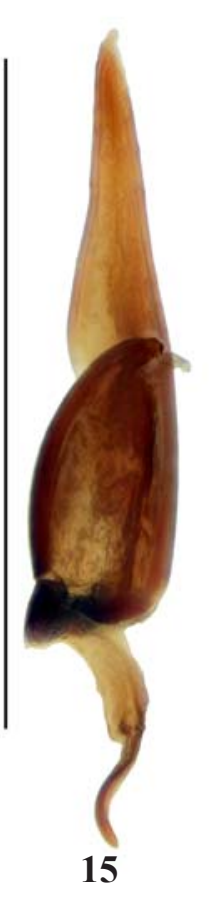

Eulycus (Lobentis) telnovi Kazantsev, sp.n.

Figs 8, 16-18.

MATERIAL: Holotype, O', E Gabon: Ogooué-Ivindo Prov., 59 km SW Makokou, Ivindo N.P., Ipassa Research Station, 0³0'52'

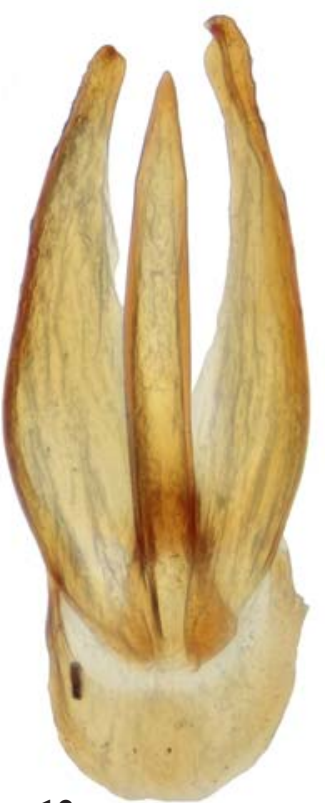

12



13

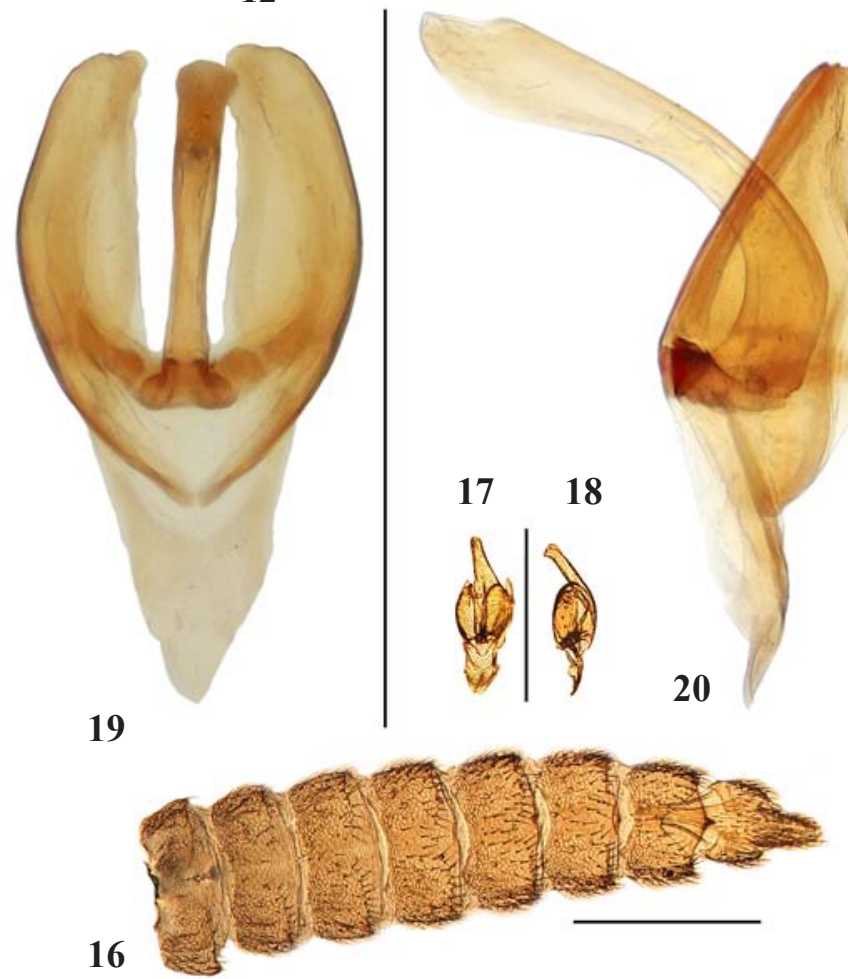

Figs 10-20. Abdomen and aedeagus of Mimolibnetis and Eulycus gen.n. spp., males: 10-12 - M. apicalis; 12-13 - M. ruwenzoriensis; 14-15 - Eulycus (s.str.) patruelis; 16-18 - E. (Lobentis) telnovi sp.n.; 19-20 - E. (L.) obscurus; 10-12, 19-20 - lectotypes; 12-13paratype; 14-18 - holotypes; 16 - abdomen; 10-15, 17-20 - aedeagus; 16 - dorsally; 10, 12, 14, 17, 19 - ventrally; 11, 13, 15, 18, 20 - laterally. Scale bars: $0.5 \mathrm{~mm}$.

Рис. 10-20. Брюшко и эдеагус Mimolibnetis и Eulycus gen.n. spp., самцы: 10-12 - M. apicalis; 12-13 - M. ruwenzoriensis; 14 15 - Eulycus (s.str.) patruelis; 16-18 - E. (Lobentis) telnovi sp.n.; 19-20 - E. (L.) obscurus; 10-12, 19-20 - лектотипы; 12-13 паратип; 14-18 - голотипы; 16 - брюшко; 10-15, 17-20 - эдеагус; 16 - сверху; 10, 12, 14, 17, 19 - снизу; 11, 13, 15, 18, 20 сбоку. Масштабные линейки: 0,5 мм. 
$\mathrm{N}, 12^{\circ} 48^{\prime} 21^{\prime \prime} \mathrm{E}, 480-540 \mathrm{~m}$, secondary lowland rainforest, UV light trap, 24-25.VI.2016, D. Telnov leg. (NME).

DESCRIPTION. Male. Light brown; antennomeres 210 and scutellum brownish testaceous; pronotum and elytra dark brown.

Elongate, narrow. Vertex shining, finely and scarcely punctate and deeply impressed behind antennal prominence. Eyes large, interocular distance ca. 1.9 times shorter than eye diameter. Maxillary palps slender, ultimate palpomere elongate, oval, pointed and glabrous distally. Antennal sockets separated by minute lamina. Antennae cylindrical, attaining to elytral middle; antennomeres 3-10 elongate, antennomere 2 about as long as wide, antennomere 3 the longest, subdivided into two parts by indistinct suture, ratio of part lengths: 1 (proximal): 2.5 (distal); antennomere 3 ca. 5 times longer than antennomere 2 and ca. 1.4 times longer than antennomere 4; antennomeres 3-11 with moderately long semi-erect pubescence (Fig. 8).

Pronotum transverse, ca. 1.8 times as wide as long, trapezoidal, with straight sides, feebly bisinuate basally and straight anteriorly, with conspicuous acute posterior and blunt anterior angles; surface alveolate, with inconspicuous traces of median suture, but without visible transverse folds. Scutellum with subquadrate, parallel-sided postnotal plate, conspicuously emarginate at apex (Fig. 8).

Elytra narrow, long, ca. 3.2 times longer than wide at humeri, dehiscent from scutellar area, with indistinct longitudinal costae; interstices with rough irregular reticulation; pubescence scarce, moderately long and erect. Femoris and tibiae straight, relatively broad; all tarsomeres narrow, lacking plantar pad (Fig. 8).

Abdomen with tergite 7 slightly triangularly protruded at distal margin and pointed medially (Fig. 16).

Aedeagus with elongate, broad proximally and conspicuously tapering distally in frontal aspect median lobe, round and sharpened at apex in lateral aspect; parameres roundish, finely dentate distally, ca. 2 times shorter than median lobe; phallobase elongate, concave in distal half, with complete median suture and noticeable lateral apodemes, ca. 0.5 length of median lobe (Figs 17-18).

Female. Unknown.

Length: $2.3 \mathrm{~mm}$. Width (humerally): $0.5 \mathrm{~mm}$.

DIAGNOSIS. Eulycus (Lobentis) telnovi sp.n. seems to be related to $E$. (L.) obscurus, comb.n., readily distinguishable by the smaller size and more narrow body, larger eyes, trapezoidal pronotum with truncate anterior margin, and the structure of the aedeagus, with more roundish parameres and broader in dorsal aspect and slightly widened in lateral aspect median lobe (Figs 8, 17-18).

ETYMOLOGY. The new species is named after Dr. Dmitry Telnov (Riga) who collected the unique type specimen.

REMARKS. The condition of antennomere 3 of the new species, which is subdivided into two parts by an indistinct suture (Fig. 8), suggests that this could be a transition between typical Eulycus antennae and those of Lolodorfus with 11 segments [Bocáková, 2014], provided that the latter genus, upon examination of its abdominal and aedeagal structures, proves to be a mimolibnetine.

Eulycus (Lobentis) obscurus (Pic, 1936), comb.n. Figs 9, 19-20.

Mimolibnetis obscurus Pic, 1936: 33.

MATERIAL. Lectotype, $\sigma^{\top}$, 'Cameroun: Lolodorf (Conradt)', 'Mimolibnetis obscurus n. sp.' (Pic's manuscript labels) (MNHN).
DISTRIBUTION. Known only from Cameroon (Fig. 1).

\section{Lampyrolycini Kazantsev, tr.n.}

Type genus: Lampyrolycus hulstaerti Burgeon, 1937.

DIAGNOSIS. Lampyrolycini Kazantsev, tr.n. may be distinguished from Mimolibnetini by the following presumably apomorphic combination of features, free labium, completely separated from mesepisternum by a suture mesoventrite (Fig. 22) and location of the abdominal spiracles at the edge of sternites (Fig. 24). Additionally it may be distinguished by the larger size, strongly flattened antennae, prominently raised median pronotal keel (Fig. $21)$, presence of a wedge cell in the hind wing venation (Fig. 23), short and non-contiguous hind coxae (Fig. 22), triangularly incised posteriorly, nearly straight anteriorly and medially divided by suture penultimate tergite with bifurcate posterior process (Fig. 25) and very narrow phallobase (Figs 26-27).

COMPOSITION. Lampyrolycini Kazantsev, tr.n. includes only its type genus, Lampyrolycus Burgeon, 1937.

DISTRIBUTION. Western part of the Afrotropical region (Fig. 1).

\section{Lampyrolycus Burgeon, 1937}

Type species: Lampyrolycus hulstaerti Burgeon, 1937 (by monotypy).

COMPOSITION. Lampyrolycus Burgeon, 1937 includes two species, L. bicolor Kazantsev, 1999 and L. hulstaerti Burgeon, 1937.

DISTRIBUTION. Western part of the Afrotropical region (Equatorial Guinea and Congo) (Fig. 1).

BIOLOGY. Nothing is known on the biology of Lampyrolycus.

Lampyrolycus hulstaerti Burgeon, 1937

Lampyrolycus hulstaerti Burgeon, 1937: 152.

MATERIAL. Holotype, o', 'Musée du Congo, Equateur: Boende, 19.II.1926, R.P. Hulstaert', 'Lampyrolycus hulstaerti n. sp.' (Burgeon's manuscript label) (MRAC); paratype, శ', 'Musée du Congo, Uele: Dingila, 1.VIII.1933, H.J. Brédo', 'Lampyrolycus hulstaerti m. Burgeon det. 1937' (MRAC).

DISTRIBUTION. Known from Equateur and Uele in Congo (Fig. 1).

\section{Lampyrolycus bicolor Kazantsev, 1999}

Figs 19-25.

Lampyrolycus bicolor Kazantsev, 1999: 10.

MATERIAL. Holotype, O', 'Equatorial Guinea, Evinayong, VII.1976, Petrov', 'Holotype', 'Lampyrolycus bicolor S. Kazantsev des. 1999' (printed labels) (ICM).

DISTRIBUTION. Known only from Equatorial Guinea (Fig. 1).

\section{A Key to Mimolibnetinae}

1. Larger, over $11 \mathrm{~mm}$. Antennae strongly flattened (Figs 21-22). Pronotum with prominently raised median keel (Fig. 21). Hind coxae short, separated (Fig. 22). Abdominal spiracles located at edge of sternites (Fig. 24). Penultimate tergite triangularly incised posteriorly and nearly straight anteriorly (Fig. 25). Phallobase very narrow (Figs 26-27) (Lampyrolycini tr.n.) (Lampyrolycus). ......... 2 - Smaller, less than $5 \mathrm{~mm}$. Antennae cylindrical, at least in terminal antennomeres; pronotum with inconspicuous flattened median keel at most (Figs 3-5, 8-9). Hind coxae elongate, contiguous (Fig. 4). Abdominal spiracles located at edge of tergites (Fig. 16). Penultimate tergite semi-circularly incised posteriorly and anteriorly 

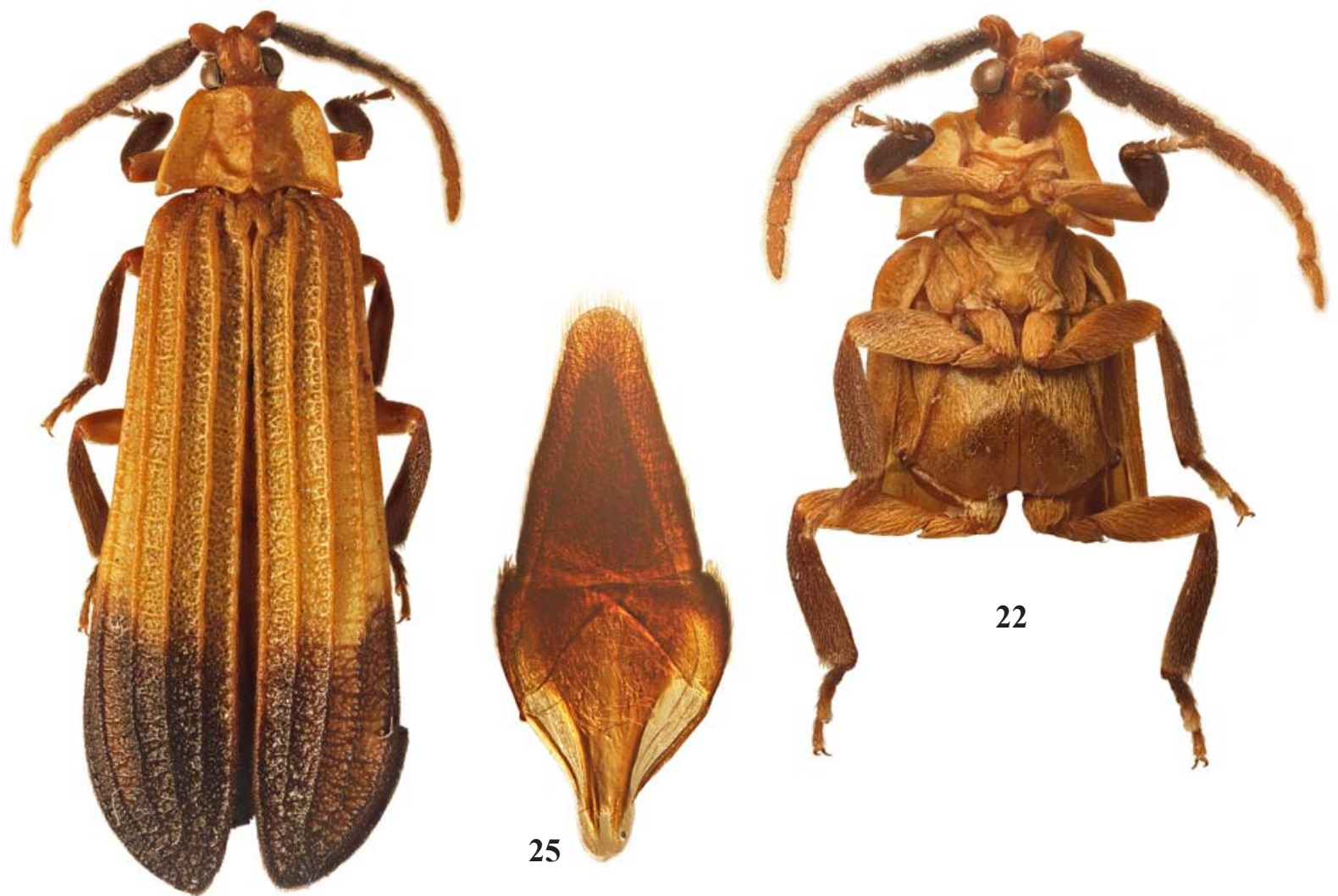

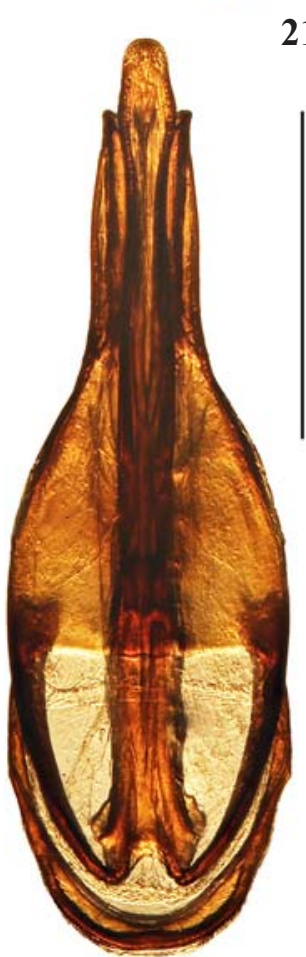

26
21

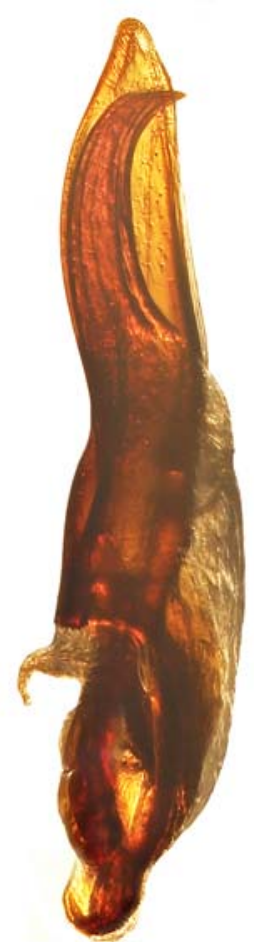

27

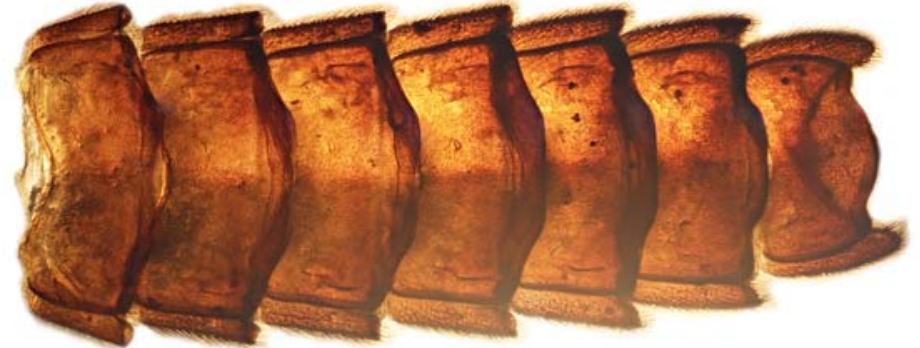

24

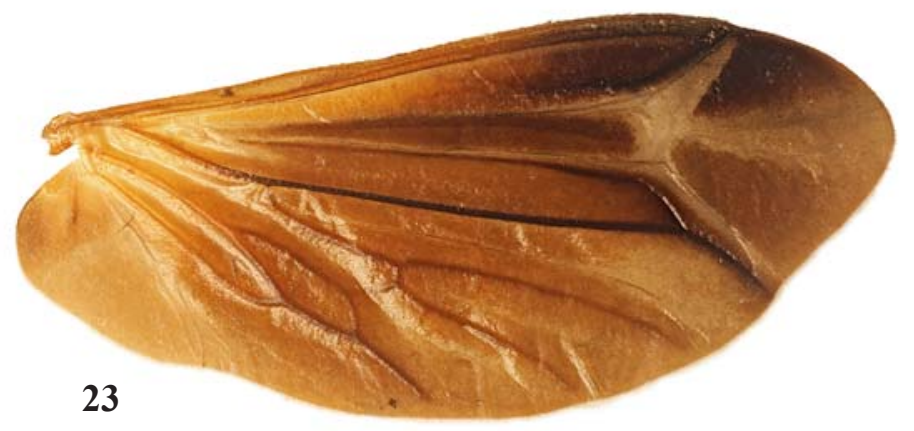

23

Figs 21-27. General view and details of Lampyrolycus bicolor, holotype, male: 21 - general view; 22 - anterior half; 23 - hind wing; 24 - abdomen; 25 - terminal abdominal segments; 26-27 - aedeagus; $21,24-25$ - dorsally; $22-23,26$ - ventrally; 27 - laterally. Scale bar: $1.0 \mathrm{~mm}$.

Рис. 21-27. Общий вид и детали строения Lampyrolycus bicolor, голотип, самец: 21 - общий вид; 22 - передняя половина; 23 - заднее крыло; 24 - брюшко; 25 - вершинные сегменты брюшка; 26-27 - эдеагус; 21, 24-25 - сверху; 22-23, 26 - снизу; 27 - сбоку. Масштабная линейка: 1,0 мм. 
(Fig. 16). Phallobase broader (Figs 10-15, 17-20) (Mimolibnetini) 3

2. Elytra uniformly testaceous, antennomeres 3-10 dark brown to black (Congo).....

L. hulstaerti

- Elytra bicoloured, antennomeres 3-6 dark brown to black, 6-10 rufous (Fig. 21). (Aedeagus - Figs 26-27) (Eq. Guinea)

L. bicolor

3. Tergites 6-7 prominently semi-circularly produced at distal margin, not pointed medially (e.g., Fig. 3). Phallobase short, broadly rounded posteriorly; median lobe subequal in length to parameres (Figs 10-13) (Mimolibnetis)

4

- Tergites 6-7 only slightly produced at distal margin and pointed medially (Figs 5, 16). Phallobase tapering posteriorly, usually elongate; median lobe about twice as long as parameres (Figs 14-15, 17-20) (Eulycus gen.n.) .. 7

4. Elytra shortened, leaving half of abdomen exposed, testaceous (Fig. 3) (Ruwenzori, E Congo)

M. ruwenzoriensis

- Abdomen fully covered by elytra. Elytra dark brown to black or bicoloured (e.g., Fig. 2)

5. Elytra dark brown to black, with testaceous humeri (Congo) M. indigenus

- Elytra mostly testaceous, only apices dark brown to black (e.g., Fig. 2)

6. Abdomen (except two apical segments), tibiae and tarsi dark brown to black (Fig. 2) (Congo) ......... M. apicalis

- Uniformly testaceous, only apical part of elytra dark brown to black (Eq. Guinea) .................... M. baguenai

7. Phallobase about as long as wide, its lateral apodemes prominent; median lobe in lateral aspect straight (Figs 14 15). Antennomere 1 lighter than other antenomeres (Fig. 5) (Eulycus s.str.) (Cameroon)

E. (s.str.) patruelis

- Phallobase noticeably elongate, its lateral apodemes inconspicuous; median lobe curved or bent in lateral aspect (Figs 17-20). Antennomere 1 darker or similar in coloration to other antenomeres (Figs 8-9) (Eulycus subg. Lobentis, subgen.n.)
8. Larger, about $4 \mathrm{~mm}$, and broader (Fig. 9). Median lobe of aedeagus noticeably widened distally, both in frontal and lateral aspects (Figs 19-20) (Cameroon)

E. (L.) obscurus

- Smaller, $2.3 \mathrm{~mm}$, and more narrow (Fig. 8). Median lobe of aedeagus distally tapering in frontal and round and sharpened at apex in lateral aspect (Figs 17-18) (Gabon)

E. (L.) telnovi sp.n.

ACKNOWLEDGEMENTS. I would like to extend my gratitude to Dr. Dmitry Telnov (Riga) for the opportunity to study lycids collected during his trip to Gabon. My sincere thanks are also due to Prof. K.V. Makarov (Moscow) for his help with some of the photos (Figs 10-15 and 19-20).

\section{References}

Bocáková M. 2014. Lolodorfus, a new genus of net-winged beetles (Coleoptera, Lycidae) from Cameroon // Zootaxa. Vol.3811. No.3. P.374-380.

Burgeon L. 1937. Un genre nouveau de Malacodermes // Revue de Zoologie et de Botanique Africaines. T.30. Fasc.1. P.152-153.

Kazantsev S.V. 1999. Revision of African genera Lampyrolycus Burgeon, 1937 and Mimolibnetis Pic, 1936 with notes on higher classification of the family (Coleoptera, Lycidae) // Elytron. Vol.13. P.7-18

Kazantsev S.V. 2005. Morphology of Lycidae with some considerations on evolution of the Coleoptera // Elytron. Vol.17-18 (2004)/Coleopterological Monographs. Vol.3. P.73-248.

Kazantsev S.V. 2013. New and little known taxa of "neotenic" Lycidae (Coleoptera), with discussion of their phylogeny // Russian Entomological Journal. Vol.22. No.1. P.9-31.

Kazantsev S.V. 2015. New species of the subgenus Elgodexoris (genus Dexoris) and a new genus of the tribe Dexorini (Leptolycinae) from East Africa, with notes on the status of Mimolibnetinae (Coleoptera: Lycidae) // Zoosystematica Rossica. Vol.24. No.1. P.99-107.

Pic. M. 1924. Lycides africains nouveaux // Annali del Museo Civico di Storia Naturale di Genova. Vol.51. P.161-164.

Pic M. 1936. Nouveautés diverses // Mélanges exotico-entomologiques. Vol.68. P.10-36. 